\title{
CORPORATE SOCIAL RESPONSIBILITY IN BUSINESS AND MANAGEMENT UNIVERSITY EDUCATION:THE RELEVANCY TO THE BUSINESS PRACTICES IN BULGARIA
}

\author{
Irena Slavova', Yovka Bankova" \\ University of National and World Economy, Sofia, Bulgaria
}

\section{ABSTRACT}

In the last decades corporate social responsibility (CSR) has forcefully and irreversibly become a part of the corporate actions of a growing number of companies and continues to provoke the interest of governments, international institutions, scientists and researchers. The new imperatives on CSR have increased the requirements of companies towards the education and preparation of experts with the requisite skills and competences.

The objective of the paper is to discuss how business universities meet the demand for new business models and management skills in order to help companies in Bulgaria to develop socially responsible practices.

The study is based on a web-content analysis of the curricula and study programs of all Bulgarian universities training business and management students in Bachelor and Master programs. The obtained results regarding the current status of CSR education are interpreted in the context of CSR in businesses in Bulgaria. To this end, results were used from a large-scale study by the authors on the status and trends of development of CSR in Bulgaria, thus uncovering the needs of companies operating on the Bulgarian market in terms of employees with CSR skills and competences, and showing the gap between the demand and supply of CSR education for business and management graduates in Bulgarian universities (Bachelor and Master programs). The conclusions delineate the directions in which teaching CSR-related issues should develop in higher education institutions in Bulgaria.

\section{JEL CLASSIFICATION \& KEYWORDS}

- M14 $\mid$ A22 - A23 $=$ CORPORATE SOCIAL RESPONSIBILITY - BUSINESS $=$ EDUCATION $=$ UNIVERSITIES $\backsim$ CURRICULUM - CSR-RELATED COURSES

\section{INTRODUCTION}

Global problems related to climate change and increasing poverty have significantly changed the role of business in society. 'Business as usual' is simply not an option and this imposes a significant change in 'business education as usual' (Hariharan, K., Williams,J, 2011). It is believed that integrating education for sustainability/CSR in the curriculum of business schools is necessary because it prepares students better for addressing environmental and social challenges (Albinsson, Perera, \& Sautter, 2011; Munilla, et al., 1998); provides opportunities for developing business skills by taking into account the additional, often unfavourable, effects corporate decisions and actions can have on society and the environment; helps understand the need for striking a balance between economic, environmental and social concerns in business management decisionmaking (Kolodinsky, R., Madden, T., Zisk, D.S \& Henkel, E. 2010).

Iirena_slavova@yahoo.com

"yovka.b@gmail.com

www.journals.cz
How business schools/universities meet the demand for new business models and management skills in order to help companies achieve their economic, social and environmental goals (the triple bottom line of business) and to what extent are these concepts addressed in their curriculum are questions widely debated in research literature and the subject of research in different countries. To present day, this field has not been investigated in Bulgaria and the research question "What is the status of CSR education in Bulgarian universities and to what extent it is in accordance with the socially responsible business practices in Bulgaria?" needs to be addressed. This paper aims to answer the need for an in-depth analysis and description of the extent to which CSR education is present in Bulgarian universities, as well as uncover the challenges faced by higher education institutions in Bulgaria in the future.

The paper is structured as follows: first, there is a brief literature review which aims to present the various aspects of CSR education researched in academic literature, as well as to outline the problems to be solved by business schools in the future. This is of critical importance for higher education institutions in Bulgaria, which are facing the major challenges of adapting to the European Higher Education Area. They have the opportunity to adapt their programs and courses to the new context in which they are carrying out their educational and research activities.

Next, current practices of CSR education in Bulgarian universities are analyzed and an evaluation is made of the extent to which they are prepared to meet the expectations of the business in terms of the CSR skills of managers and employees. After the methodology and the issues concerning the collection of the data were explained, the results of the web-content analysis of the curricula and study programs of all Bulgarian universities (state and private) training students in business and management of Bachelor and Master programs are analysed. In the context of socially responsible practices of the business in Bulgaria an answer to the research question is given revealed is the mismatch between the needs of the business in Bulgaria for CSR-oriented experts and the CSR education offerings.

Finally, the main conclusions are presented and the aspects of future research of the authors in the area of CSR education in Bulgaria are outlined.

\section{Literature Review}

CSR is a controversial concept (Okoye, 2009), defined in many and diverse ways (Dahlsrud, 2006), and the understanding of its nature varies from its complete denial (the business has one single responsibility - to increase profits, Friedman claims) (Friedman, 1970) to viewing it as a source of competitive advantage (Porter, M., Kramer, M. 2006), a form of strategic investment (McWilliams et al., 2006), a key factor of organizational and technological 
innovations (Nidomolu, R., C. Prahald et al. 2009), an element of the core operations of the company and its strategic management (Husted \& Allen, 2000; Molteni, 2006; Porter, Kramer, 2006; Smith, 2003). CSR continues to be the topic of animated discussions around the world, both in business and educational circles.

The opinion that business education has a defining role in the transition to sustainable development and development of CSR is widespread (AACSB, 2011; UNESCO, 2007; EC, 2011). A number of international organizations emphasize the importance and the role of education in achieving sustainable development and call for greater attention to corporate social responsibility and sustainable development in training and educating future business leaders (for example, UNESCO and the World Business Council for Sustainable Development). The EC points out that the development of CSR requires new skills, as well as changes in values and behavior. The member states can play an important role by encouraging educational institutions to integrate CSR, sustainable development and responsible citizenship in the curriculum, both in secondary and university education ( , 2011). In addition, European business schools are encouraged to adopt the UN principles for responsible management education.

Promoting environmental and social values at all levels of education is important, but the key place where future managers and employees can acquire new skills with a focus on CSR is as part of their undergraduate or graduate university education (Seto-Pamies et al., 2011). Different institutions (the academic community, governments, international organizations, corporations, etc.) support the belief that CSR should be integrated into the curriculum of higher education since universities and business schools develop future company and organization managers, and through their knowledge, skills and competences, CSR and sustainability turn into practices.

A number of publications in academic literature confirm the integration of CSR/sustainability issues in business and management education in many universities in different countries. Matten and Moon (2004) report the efforts made to "mainstream" CSR teaching and the teaching methods in Europe. Surveying a wide range of business educational institutions in different European countries, they establish that $47 \%$ of the respondents offer courses in CSR or related fields, such as citizenship, governance, business ethics etc. Seto-Pamies, Domingo-Vernis and Rabassa-Figueras (2011), based on a study of the current status and the extent of CSR teaching in management education in Spanish universities, make the conclusion that the predominant part of the universities include ethics/CSR as a standalone discipline and also embed CSR content in other academic subjects. Nevertheless, "CSR content is by no means fully developed." (Seto-Pamies et al.,2011, p.604). Different types of CSR-related courses are also available in state universities in the USA (Navarro, P.,2008; Bruce, G., Edgington, R., 2008), Czech Republic (Adamek, P. 2013), Australia (Heidt and Lamberton, (2011); Australia and New Zealand, (Rundle-Thiele and Wymer (2010); China and India (Jacob Park, J., Sarkar, R., Bunch, R., 2012) and other countries.

Sustainability/CSR can be incorporated into undergraduate and postgraduate education in a number of ways. It could be integrated in existing business programs both by adding a dedicated course on sustainable development/CSR and by embedding the sustainable development/CSR concepts and tools in the topics of existing courses (Bridges \& Wilhelm 2008; Matten and Moon, 2004; Heidt, T., and Lamberton,
G., 2011, Seto-Pamies et al., 2011; Christensen, L.J. et al. (2007). The greatest challenge faced by universities, and the one which is most difficult to resolve, is the necessity to incorporate sustainability/CSR in the official curriculum of business sciences (Heidt and Lamberton, 2011; Matten and Moon, 2004). This necessity stems from the understanding that has been established in academic literature and practice for more than a decade (White, 2005) that CSR can create benefits for the companies when incorporated in their operations and corporate social activities are part of the organization's strategy and related to its goals (Porter, M., \& Kramer, M.,2006, 2011).

Incorporating sustainability/CSR as a strategic consideration into daily business decisions depends on the organizational development of a range of skills and capabilities (Dunphy, D., Griffiths \& Benn, 2007). Corporations require knowledge and skills with a focus on sustainability/CSR from different types of experts in the field of marketing, accounting, finances, human resources, etc., which makes it necessary to integrate CSR into the core business courses. The principles of sustainability must be integrated into each and every module of an MBA programme, in order for knowledge to seep in, in a holistic fashion (Hariharan, K., Williams, J.,2011), which is why holistic and integrated approaches to sustainability/CSR education have a much greater effect on students and employee development (Winter, J., Barton, G., Cotton, D, 2015).

Many researchers maintain this viewpoint and research the area from different perspectives: current practices and opportunities for embedding CSR in core strategic management courses (Audebrand, 2010), integrating CSR and sustainability in marketing education (Borin, N. \& Metcalf, L. 2010; Bridges, C. \& Wilhelm, W., 2008); embedding sustainability in the accounting curriculum (Sharma, U, Stewart, B \& Kelly, M., 2012) and teaching ethics in the financial planning curriculum (Overton, R. 2006); barriers to education for sustainability in the tourism curriculum (Erica Wilson, Tania von der Heidt, 2013); developing a process for integrating sustainability content in the core Legal Environment for Business course, which can be applied to any core course part of the curriculum (James Sanford, J., Motwani, J., 2013).

The factors on which embedding CSR in the curriculum of core business courses depends are multiple and complex (Matten and Moon, 2004; Bruce, G., Edgington, R., 2008; Albinsson, P., Perera, Y., Sautter, P., 2011), but one key factor is the good interaction between the different stakeholders, and that can be achieved through developing a proposal for value for each of the stakeholders (faculties, business partners, lecturers, etc). (Benn, S., Dunphy, D., Low, S., Perey, R., 2009).

The great diversity of academic publications related to CSR and education, as well as the different perspectives from which they are studied show its multi-aspect nature and the fact that there is no universal solution on how to implement it. The growing number of companies carrying out corporate social initiatives and their wider range heighten interest in teaching CSR at different levels. Undoubtedly, the national context has an influence on CSR of the business and education, despite the growing globalization processes.

Analysis of CSR teaching in business and management educationin Bulgarian universities

Methodology

This part of the paper reports the conclusions of the study on the extent to which CSR is taught in business and management education in Bulgarian universities. Similar to 
other publications in the field of CSR education (Navarro,P., 2008; Rezaee, Z, Homayoun, S., 2014; Seto-Pamies, Domingo-Vernis and Rabassa-Figueras, 2011), the method of analysis chosen is a web-based content analysis. The advantages of this method are related mainly to the open access to information. School web sites are an official source of information that is accessible to the public, regularly updated and used commonly by the stakeholders. It should be noted that the statistical results from all webbased studies are influenced by the available data, the frequency with which they are updated and the language of use (Wu et al., 2010), which requires a careful interpretation of the obtained results. The present study also encountered typical content analysis constraints related to the available data and more specifically, to the different way in which the universities present information about the courses and curriculum studied. We believe that this does not have an impact on the main conclusions of our study (regarding the general status of CSR teaching in business and management education) since no significant difference was found between the curricula of Bulgarian universities. The obtained results and the conclusions regarding the extent to which higher education institutions offer CSR-related courses are of great significance since they uncover problems in CSR education, show the gap between the CSR education offered to business and management graduates in Bulgarian universities (Bachelor's and Master's degree programs) and the expectations of the business in relation to the CSR skills of managers and employees, they delineate the challenges standing before universities in Bulgaria and are a starting point for future research.

Data collection

In order to analyze CSR education in universities in the Bulgarian context, the study included the educational institutions which offer business and management programs and identified the types of CSR-related courses they offer. The focus of the study is higher educational institutions that provide business and management education to students the universities which have within their structure Business and Management faculties and/or departments. Due to the extremely high number of universities in Bulgaria,relative to the population and the territory of the country, in comparison to the other EU member states, (Strategy for Development of Higher Education in Bulgaria, 2014, p. 9) the scope of the study includes only the universities that have obtained accreditation from the National Evaluation and Accreditation Agency in the professional fields Administration and Management and Economics for Bachelor's and Master's degrees. According to data from the national register of the Ministry of Education and Science, out of 51 accredited higher education institutions in Bulgaria, 26 provide Business and Management education to students. The Bulgarian educational system distinguishes between public and private higher education institutions, depending on the way of funding. The target group of the study includes both state (19) and private (7) universities. Since the aim is to present the status of CSR education in Bulgarian universities, the American University in Bulgaria was excluded from the list. The variety of higher education institutions delivering business and management education can be divided into three groups:

1. mainly Economic higher education institutions;

2. mainly Technical higher education institutions with a faculty of economy, including business, management and administration specialties and departments (technical sciences are predominant);

www.journals.cz
3. higher education institutions offering education in different fields of science $^{3}$ (more than 5 - natural sciences, humanities, economic sciences, arts, etc.). In their structure they have a Faculty of Economy with Business, Management and Administration specialties and departments.

Since there is no uniform database in Bulgaria to register the disciplines and programs studied, an independent study was carried out of the websites of all universities included in the scope of the present research. The business and management curriculum published on the websites of the higher education institutions, as well as the descriptions of the Bachelor and Master programs, were examined in order to determine which of them contain CSR-related courses at present.

For the purposes of the study, two additional methodological questions need to be clarified:

- What does "university" mean in Bulgaria? According to the Bulgarian Higher Education Act, a university is a higher education institution which provides training for the Bachelor, Master and Doctor degrees in the respective main branches of science and has been accredited by the National Evaluation and Accreditation Agency with the Council of Ministers. Universities can be financed with public funds or private ones (Higher Education Act, supplemented and amended, SG, issue 56 of 24 July 2015).

- What does CSR education mean in the present study? A wide range of names is used for CSR-related courses, which stems from the very nature of CSR as a concept. As was already pointed out, it is a controversial concept (Okoye, A., 2009), defined in many different ways (Dahlsrud, 2006); in most cases, CSR is interpreted as an "umbrella term". "The term "corporate social responsibility' is still in popular use, even though competing, complementary and overlapping concepts such as corporate citizenship, business ethics, stakeholder management and sustainability are all vying to become the most accepted and widespread descriptor of the field." (Carroll, A., Shabana, K., 2010, p.86). The situation in the field of CSR education is similar - a variety of synonymous terms is used to name the disciplines, such as Business Ethics, Corporate Citizenship, Sustainability, Corporate Environmental Management, Business and Society, Business and Governance, Business and Globalization, Stakeholder Management, Governance (Matten and Moon, 2004).

The inner complexity of CSR - the need for a balance between economic, legal, ethic and social responsibilities (Carroll, A., 1991) towards a number of stakeholders (Freeman, R. E., Wicks, A. C. and Parmar, B., 2004) - is a prerequisite for its multi-aspect and expanding scope. CSR concerns complex issues, such as environmental protection, human resources management, health and safety at work, relationships with local communities, relationships with suppliers and consumers (EC, 2011). In the updated CSR strategy of EC, this scope is expanded in accordance with the international principles and guidelines.

The study of the curricula of the business and management Bachelor and Master programs in Bulgarian higher education institutions targeted disciplines that contained

3 The Higher Education Act provides a classifier for the areas of higher education (by fields of science $-\mathrm{a}$ total of 9 - humanities, technical, economic and legal sciences, arts, etc.) and professional fields are differentiated within each area (Higher Education Act, supplemented and amended, SG, issue 56 of 24 July 2015. 
CSR or its synonyms in their names. In addition, with view of EC's understanding of the wide scope of CSR and the principles of the UN Global Compact, courses related to human resources management, health and safety at work, social policy/social entrepreneurship were also identified. In the curriculum of these courses, CSR is included as separate topics or individual modules.

\section{Analysis of the results}

The analysis identified the integration of CSR-related courses in business and management education in Bulgarian universities by answering the following questions:

- Do these universities offer CSR-related courses?

- Which of these disciplines are elective or mandatory?

- Which of these courses are offered in the Bachelor and/or the Master programs?

- Does the extent of CSR education meet the needs of the business for CSR-oriented experts?

The diversity of the concept of CSR education is illustrated by the fact that universities in Bulgaria use many different names for the courses offered as mandatory or elective disciplines at different levels of education - one and the same discipline is offered in the Bachelor program in some universities, and in others it is part of the Master program (see Table 1). The wide range of names for CSR-related courses offered by Bulgarian universities is systematized into groups with names of disciplines, viewed as CSR synonyms: Sustainable development $(20 \%$ of all disciplines from the sample), Business ethics (11.5\%), Environmental Management (13.0\%), Ecology and Environmental Protection $(7.8 \%)$, CSR $(4,8 \%)$. Within each of these groups, there is also a diversity of names, but in their essence, the curricula are the same. Sustainable Development is either offered as a separate course, or another theme is included in the name, for example "Sustainable Development and Globalization"; the situation is similar with environmentrelated subjects - different names are used - Environmental Management, Environmental Management and Monitoring, Environmental Economics, Economics and Environmental Management, etc.

\begin{tabular}{|l|l|l|l|}
\hline $\begin{array}{l}\text { Table 1: CSR-related courses offered in Bulgarian universities in } \\
\text { the business and management Bachelor and Master programs }\end{array}$ \\
\hline Courses & Total (\%) & $\begin{array}{l}\text { Bachelor } \\
\text { programs } \\
(\%)\end{array}$ & $\begin{array}{l}\text { Master } \\
\text { programs } \\
(\%)\end{array}$ \\
\hline Sustainable Development & 20,0 & 137 & 33,3 \\
\hline Environmental Management & 13,0 & 9,8 & 15,8 \\
\hline $\begin{array}{l}\text { Ecology and Environmental } \\
\text { Protection }\end{array}$ & 7,8 & 12,6 & \\
\hline Business Ethics & 115 & 9,8 & 12,7 \\
\hline Corporate Social Responsibility & 4,8 & 3,6 & 6,3 \\
\hline Human Resource Management & 23,6 & 31,9 & 9,5 \\
\hline $\begin{array}{l}\text { Social Policy/Social } \\
\text { Entrepreneurship }\end{array}$ & 15,7 & 15,7 & 17,4 \\
\hline $\begin{array}{l}\text { Health and Safety Working } \\
\text { Conditions }\end{array}$ & 3,6 & 2,9 & 50 \\
\hline Total (\%) & 100,0 & 100,0 & 100,0 \\
\hline Source: Websites of universities, study of the authors \\
\hline
\end{tabular}

As already stated, the scope of the study includes the courses complementing the analysis - Human Resources Management (23.6\%) and Social Policy/Social Entrepreneurship (15.7\%). They are available in almost all business and management curricula in Bulgarian www.journals.cz universities as mandatory subjects (CSR issues are included as a separate topic or module) and are mainly offered in the Bachelor programs. There are no differences in the name used for Human Resources Management.

Although all groups of CSR-related disciplines are offered both in the Bachelor and Master programs (see Table 1), most courses named with CSR synonyms (sustainable development, business ethics and CSR) are offered in Master programs as elective courses. The publications in academic literature showed that this is also the practice of universities in other countries (Matten and Moon, 2004; Adamek, P., 2013; Seto-Pamies, Domingo-Vernis and Rabassa-Figueras (2011), Segon . and Booth Ch.,2009). According to Matten and Moon, the fact that the predominant part of universities include CSR-related courses as elective courses means that there is no fundamental change in business schools as yet (Matten and Moon, 2004).

Interpretation of results in the context of socially responsible practices of the business in Bulgaria

The disciplines related to environmental problems (Environmental Management; Ecology and Environmental Protection) and Sustainable development are the ones most often offered in universities - approximately $50 \%$ of all disciplines from the sample. This is not surprising since the concept of sustainable development has been known in Bulgaria for some years and has gained popularity. The fact that courses on corporate environmental management, sustainable development and environmental protection are more widely included in higher education in Bulgaria can be explained through the existing environmental legislation, the introduction and practice of environmental impact assessment, the growing number of companies who have obtained ISO 14000 , the corporate social activities carried out by the business related to achieving an economic and environmental effect, etc. Our detailed study of CSR in Bulgaria under a research project of University of National and World Economy (UNWE) (Slavova, I., Bankova Y., 2014) shows that most frequently applied by the businesses are socially responsible practices for enhancing the efficiency of production processes which lead to a reduction of expenses for natural resources (water, energy, waste, etc.) and improving the environment. Technological innovations, large-scale and long-term programs in the environmental field are part of the activities of several large companies operating on the Bulgarian market (the study of corporate social initiatives, published on the web pages of the companies operating on the Bulgarian market, showed that such practices are a characteristic of 10 out of the 68 companies surveyed).

Arguments for the necessity of studying environment-related disciplines are also provided by the results of the conducted empirical study under the same project (200 companies were surveyed, $80 \%$ of which - small and medium-sized enterprises). The representatives of the small and mediumsized business identify environmental problems as the most significant and are inclined to support environment-related initiatives ( $82 \%$ of the respondents), but it is only $32.4 \%$ that implement such initiatives.

Although environment and sustainability related subjects are predominant amongst those studied at universities in Bulgaria, a number of aspects related to environmental responsibility also require a wider presence in the teaching process - the EU voluntary schemes. According to the results of the survey cited above, the businesses $(67 \%$ of the companies surveyed) are not familiar with the European Eco-Management and Audit Schemes (EMAS) and 


\begin{tabular}{|c|c|c|c|c|c|c|c|c|c|}
\hline \multirow[b]{2}{*}{ № } & \multirow[b]{2}{*}{ Universities } & \multicolumn{8}{|c|}{ Courses } \\
\hline & & $\begin{array}{l}\text { Sustainable } \\
\text { Development }\end{array}$ & $\begin{array}{c}\text { Environmental } \\
\text { Management }\end{array}$ & \begin{tabular}{|c|} 
Ecology and \\
Environmental \\
Protection \\
\end{tabular} & $\begin{array}{c}\text { Business } \\
\text { Ethics }\end{array}$ & \begin{tabular}{|c|}
$\begin{array}{c}\text { Corporate } \\
\text { Social } \\
\text { Responsibility }\end{array}$ \\
\end{tabular} & \begin{tabular}{|c|} 
Social Policy/ \\
Social \\
Entrepreneurship \\
\end{tabular} & \begin{tabular}{|c|} 
Human \\
Resource \\
Management \\
\end{tabular} & $\begin{array}{c}\text { Health and } \\
\text { Safe Working } \\
\text { Conditions } \\
\end{array}$ \\
\hline 1 & Agricultural University & & & $\checkmark$ & & & & $\checkmark$ & \\
\hline 2 & Angel Kanchev University of Ruse & & & & & & $\checkmark$ & $\checkmark$ & \\
\hline 3 & Burgas Free University & $\checkmark$ & $\checkmark$ & & $\checkmark$ & & $\checkmark$ & $\checkmark$ & \\
\hline 4 & D. A. Tsenov Academy of Economics & $\checkmark$ & $\checkmark$ & $\checkmark$ & $\checkmark$ & $\checkmark$ & & $\checkmark$ & \\
\hline 5 & International Business School & & & $\checkmark$ & & & & $\checkmark$ & \\
\hline 6 & New Bulgarian University & $\checkmark$ & $\checkmark$ & & & $\checkmark$ & & $\checkmark$ & $\checkmark$ \\
\hline 7 & Plovdiv University "PaisiiHilendarski" & $\checkmark$ & & $\checkmark$ & & & $\checkmark$ & $\checkmark$ & \\
\hline 8 & Prof. D-r. Assen Zlatarov University & & & & & $\checkmark$ & $\checkmark$ & & $\checkmark$ \\
\hline 9 & Sofia University St. Kliment Ohridski & & & & $\checkmark$ & & & $\checkmark$ & \\
\hline 10 & South-West University "NeofitRilski" & $\checkmark$ & & & & $\checkmark$ & $\checkmark$ & $\checkmark$ & \\
\hline 11 & St. Cyril and St. Methodius university & $\checkmark$ & & $\checkmark$ & $\checkmark$ & $\checkmark$ & $\checkmark$ & $\checkmark$ & \\
\hline 12 & Technical University - Gabrovo & & & $\checkmark$ & $\checkmark$ & & $\checkmark$ & $\checkmark$ & $\checkmark$ \\
\hline 13 & Technical University of Sofia & & $\checkmark$ & & $\checkmark$ & & $\checkmark$ & $\checkmark$ & \\
\hline 14 & Technical University-Varna & & $\checkmark$ & & & & $\checkmark$ & $\checkmark$ & $\checkmark$ \\
\hline 15 & Todor Kableshkov University of Transport & & & & & & & $\checkmark$ & \\
\hline 16 & Trakia University - Stara Zagora & $\checkmark$ & & $\checkmark$ & & & & $\checkmark$ & \\
\hline 17 & University of Agribusiness and Rural Development & & & $\checkmark$ & & & & $\checkmark$ & \\
\hline 18 & University of Chemical Technology and Metallurgy & & $\checkmark$ & $\checkmark$ & & $\checkmark$ & $\checkmark$ & $\checkmark$ & \\
\hline 19 & University of Economics - Varna & & $\checkmark$ & & $\checkmark$ & $\checkmark$ & & $\checkmark$ & $\checkmark$ \\
\hline 20 & University of Finance, Business and Entrepreneurship & $\checkmark$ & & & & $\checkmark$ & & $\checkmark$ & \\
\hline 21 & University of Food Technologies & & & $\checkmark$ & & & & $\checkmark$ & \\
\hline 22 & University of Forestry & & & & & & & $\checkmark$ & \\
\hline 23 & University of National and World Economy & $\checkmark$ & $\checkmark$ & $\checkmark$ & $\checkmark$ & $\checkmark$ & $\checkmark$ & $\checkmark$ & $\checkmark$ \\
\hline 24 & Varna Free University „Chernorizets Hrabar“ & & & & & & $\checkmark$ & $\checkmark$ & \\
\hline 25 & Vasil Levski National Military University & & $\checkmark$ & $\checkmark$ & & & & & $\checkmark$ \\
\hline
\end{tabular}

Ecolabel, and practice shows that there are only 3 organizations in Bulgaria registered with EMAS and none with Ecolabel. In this respect Bulgaria is falling significantly behind the other EU member states.

The relatively low number of standalone disciplines named CSR (Business ethics $-11.5 \%$ and CSR $-4.8 \%$ of all subjects included in the sample), as well as the lack of disciplines synonymous to CSR, such as Corporate Citizenship, Business and Society, Business and Governance, Business and Globalization, Stakeholder Management, Governance can be explained with the fact that CSR is a relatively new concept and practice in Bulgaria - its beginnings can be traced back to 2001 - 2002. In contrast to the experience in Western Europe, where CSR appeared as a result of the severe criticism of the media and customer requirements for reducing or compensating the negative impact of the business on society and the environment, in Bulgaria and other Eastern European countries the idea and practice for corporate social initiatives came from the businesses themselves - large international companies supported by international institutions (most often the United Nations Development Program). The national context also had an effect on the trends in CSR education - in western universities CSR and ethics are the www.journals.cz most frequently used terms with a tendency towards a wider use of the term "sustainability" (Christensen et al., 2007; Rezaee, Z., Homayoun, S, 2014), whereas in Bulgaria only a few higher education institutions included CSR as a standalone discipline in their curriculum and it has started to appear in the curriculum in the past few years.

The conclusions from the analysis show that CSR education is present in Bulgarian universities. As can be seen from Table 2, the predominant part of the universities studied include CSR-related subject(s) in business and management education, but only $20 \%$ of the higher education institutions require business and management students to cover more (two or three) CSR-related courses (ethics, CSR, sustainable development, environmental management). This shows that CSR education is still not widely addressed in business and management higher education. There is no significant difference between the different types of universities, which shows that there are no significant differences in the curricula of business and management education in Bulgarian universities.

One positive fact is the existence of a standalone Corporate Social Responsibility (Financial Management) Master's 
programme offered by the University of Finance, Business and Entrepreneurship located in Sofia with the support of the United Nations Global Compact Network Bulgaria, Intertek and CSR Bulgaria.

Bulgarian universities offer standalone CSR-related courses in Bachelor and Master programs. The advantage of this approach is that CSR has its clearly defined identification within the disciplines taught in business and management education. The standalone CSR disciplines provide fundamental knowledge about the concept and can afford to dedicate a lot more time and opportunities for developing the relationships between CSR and other disciplines, as well as illustrate the interaction between the three dimensions economic, social and environmental (Stubbs, W. and C. Cocklin, 2008). Such knowledge is undoubtedly necessary for future business experts and managers since, as stated above, CSR in Bulgaria is still in the initial stages of development and it is not known as a concept among the small and medium-sized enterprises. As shown by the results of the empirical study cited above, the small and medium-sized enterprises are not well-acquainted with the essence of the CSR concept $-62.5 \%$ of representatives of the business have a very general idea of CSR and view CSR from the perspective of "the right thing to do" and not as a strategic issue for their better future development. Business representatives in Bulgaria associate CSR with improving the company image $(67.5 \%$ of all respondents) and do not find economic and financial benefits from implementing corporate social initiatives (only $11.2 \%$ believe that such benefits might exist). Although according to the representatives of the business, the main reason for the absence of socially responsible practices are the limited financial resources, the study showed that most of the companies operating on the Bulgarian market (especially small and medium-sized businesses) do not have the necessary knowledge regarding the essence and forms of CSR, the opportunities for improving competitive advantages, etc. This clearly illustrates the need to prepare CSR-oriented experts.

CSR education as a standalone discipline runs the risk of being viewed as a separate issue isolated and unrelated with the core business courses (Hariharan, K., Williams, J, 2011). According to Mattenand oon, CSR education should do something different for the business - CSR should not be taught in separate modules, but should be embedded in core business education (Matten and oon, 2004). Many researchers and practitioners share the belief that CSR should be embedded in the curriculum at different levels of education because "mainstreaming" teaching provides opportunities for every business student to be informed about the social and ethical dimensions in their future work as a business person.

The question concerning the embedding of CSR in core business courses in business and management education in Bulgarian universities is not included in the present research since it requires a separate study. However, our direct observations as members of the Faculty Board on Administration and Management and the Marketing and Strategic Planning Department of the University of National and World Economy, Sofia, are that CSR issues are not integrated into the core business courses on management, strategic planning, marketing (which are mandatory in our faculty). We believe that this is one of the main problems standing before CSR education and a challenge for higher educational institutions, resulting both from the adopted practice of universities in other countries (Matten and oon, 2004; Seto-Pamies, Domingo-Vernis and Rabassa-
Figueras, 2011, Hariharan, K., Williams, J., 2011; Stubbs, W. and C. Cocklin. 2008), as was shown in the literature review, and from the emerging trends in the development of CSR in Bulgaria. The abovementioned study of the websites of companies operating on the Bulgarian market showed that the number of companies implementing CSR is increasing, the number of corporate social initiatives is growing, the activities and participation of different companies has also increased significantly since Bulgaria joined the EU. The corporate social initiatives that are being implemented are diverse in form and a tendency can be observed towards a transition from the traditional form of corporate philanthropy (donating money) to more strategic forms of CSR.

The international companies operating on the Bulgarian market carry out active CSR, apply a strategic approach in its development and follow the CSR policy of the mother company. The analysis of CSR initiatives published on the websites of companies operating in different economic sectors in Bulgaria distinguished a number of companies (19 from a total of 68), which stand out with the complex and long-term CSR initiatives they implement and the application of a planning process, implementation and assessment of CSR strategies and programs. Most of these companies are part of international organizations and have established structural units and systems for corporate social accountability. They respond to the needs of a wide range of stakeholders via different forms of CSR initiatives. The application of a strategic approach to CSR, the need to filter all strategic decisions through the CSR perspective in order to ensure optimal results for different stakeholders, incorporating CSR into company operations (systems, structures and processes) all place new requirements on managers at different levels. In this respect, the CSR education offered to business and management graduates in Bulgarian universities (from Bachelor and Master programs) does not meet the expectations and needs of the business in terms of CSR skills of managers and employees. The challenge faced by higher education on business and management is how to integrate CSR issues first and foremost in the core business courses on strategic management, strategic planning, marketing, finances, accounting, etc.

Taking into account the development of CSR in Bulgaria, which also predetermines the needs of the business for experts with CSR skills and competences, we believe that in Bulgarian universities CSR education should be incorporated both as standalone CSR subjects, and embedded in the core business courses. At the present stage, the CSR education offered does not meet the needs of the business in Bulgaria, whilst the growing number of companies, implementing corporate social initiatives, as well as the tendency towards incorporating CSR into the company strategy, both urgently require business experts and managers at different management levels with CSR-related knowledge, skills and competences.

It is imperative that the universities develop new methodologies and frameworks to facilitate students in the understanding of CSR/sustainability in the business environment (Auderbrand, L., 2010). However, any effort to integrate CSR/sustainability in business and management education in universities requires enthusiastic support at different levels. The main drivers for including courses on corporate social responsibility and sustainability in higher education are the members of the management of universities, faculties and departments, and their decisions 
determine the selection of CSR-related disciplines (mandatory or elective), the level of education (Bachelor's and/or Master's degree programs) at which they are offered, how to include CSR in the curriculum - as a standalone discipline and/or embed corporate social responsibility and sustainable development in the core Bachelor business courses.

\section{CONCLUSION}

The present paper reviews issues related to the extent and way higher education institutions in Bulgaria include the broad CSR topic in business and management education. One of the main results is that a high percentage of the universities (more than $80 \%$ ) include CSR-related disciplines as standalone courses in their curricula; however, more in-depth analysis of the data shows that only $20 \%$ of the universities require business and management students to cover more (two or three) CSR-related courses (ethics, CSR, sustainable development, environmental management). The latter are offered as elective courses, which presupposes, that business and management graduates from state and private universities do not have basic skills in this fields.

The evaluation of the status of the CSR education offered by Bulgarian universities was made in the context of corporate socially responsible practices of the business in Bulgaria. The data used were the results of a large-scale study on CSR in Bulgaria, carried out by the authors under a research project of UNWE. When we relate the results from the study of CSR education in Bulgarian universities and the results from the survey of the status and tendencies of CSR in Bulgaria, we can make the following main conclusion: CSR teaching in business and management education in Bulgarian universities does not meet the present needs of the business in Bulgaria and there is a big gap between the needs of the business in Bulgaria for CSR-oriented experts and the CSR education offerings. The expected tendency for an increase in the CS initiatives of the companies operating on the Bulgarian market and the application of strategic CSR and its integration into the business operations of the companies will place higher and higher requirements to universities in Bulgaria.

The present research is a starting point for future CSRrelated discussions and research. Future directions of research include pedagogical issues related to the teaching methods, common and divergent points in the goals and scope of the topics included in the curricula of CSR-related courses.

Since the business is developing its socially responsible practices and more and more business schools are considering incorporating CSR into their curriculum, it is necessary to conduct more in-depth studies of the content and delivery of CSR-related courses. Future research should offer insight into CSR programs and development of new courses, and, on the basis of surveys, take into account the viewpoints of both the academic community and the practitioners.

The tendency that can be observed of "mainstreaming" CSR education in universities in other countries outlines another direction of future research - the need to research the opportunities and ways in which CSR/sustainability topics can be embedded in core business courses on strategic management, strategic planning, marketing, accounting, finances, etc. offered by Bulgarian universities in the business and management education. There is a wide range of stakeholders participating in this process, which requires the active participation of deans, members of faculty boards, departments, lecturers, representatives of the business, and students.

\section{REFERENCES}

AACSB international ethics/sustainability resource center, 2011, Retrieved September 10, 2015 from http://www.greenprof.org/wpontent/uploads/2011/05/AACSB-Sustainability-in-BusinessEducation.pdf

Adamek, P., (2013) Corporate Social Responsibility Education in the Czech Republic, Retrieved September, 20, 2015, from http://www.sciencedirect.com/science/article/pii/S1877042813046 995

Albinsson, Perera, \& Sautter (2011), Integrating sustainability into the business curriculum through e-learning. Journal of Online Learning and Teaching, 7(1), pp.117-27

Audebrand, L., K., (2010). Sustainability in Strategic Management Education: The Quest for New Root Metaphors,Academy of Management Learning \& Education, Vol. 9, No. 3, pp.413-428.

Benn, S., Dunphy, D., Low, S., Perey, R. Integrating Sustainability into MBA Programs: A Multiple Stakeholder Approach, 2009 Retrieved September, 10, 2015, from http://www.anzam.org/wpcontent/uploads/pdf-manager/2056_BENN_AND_OTHERS_\%5B1 $\% 5 D . P D F$

Borin, N. \& Metcalf, L (2010) Integrating sustainability into the marketing curriculum: Learning activities that facilitate sustainable marketing practices. Journal of Marketing Education, 32 (2) pp. $140-154$

Bridges, C. M. \& Wilhelm, W. B. (2008). Going beyond green: The "why and how" of integrating sustainability Into the Marketing curriculum. Journal of Marketing Education, 30, 33-46.

Bruce, G., Edgington, R.,(2008). Ethics Education in MBA Programs: Effectiveness and Effects, International Journal of Management and Marketing Research, Volume 1, Number 1, pp. $49-69$

Carroll, A., Shabana, K. (2010). The Business Case for Corporate Social Responsibility: A Review of Concepts, Research and Practice, International Journal of Management Reviews, pp. 85- 105.

Carroll, A.B..(1991). The pyramid of corporate social responsibility: toward the moral management of organizational stakeholders. Business Horizons, July-August, pp. 39-48.

Christensen, L.J., Peirce, E., Hartman, L.P., Hoffman, W.M. and Carrier, J., (2007) "Ethics, CSR and sustainability education in the Financial Times Top 50 Global Business Schools: baseline data and future research directions", Journal of Business Ethics, Vol. 73 No. 4, pp. 347-68.

Dahlsrud A., (2006). How Corporate Social Responsibility is Defined: an Analysis of 37 Definitions, Corporate Social Responsibility and Environmental Management,Published online 9 November 2006 in Wiley InterScience, pp.1-17 (www.interscience.wiley.com).

Dunphy, D.; Griffiths, A. \& Benn, S. (2007), Organizational Change for Corporate Sustainability. Guide for leaders and change agents of the future. 2nd Ed. London: Routledge.

European Commission, A renewed EU strategy 2011-14 for Corporate Social Responsibility, Brussels, 25.10.2011, COM (2011) 681.

Freeman, R. E., Wicks, A. C. and Parmar, B. (2004). Stakeholder Theory and 'The Corporate Objective Revisited, Organization Science, Vol. 15 No. 3, pp. 364-369.

Friedman, M. (1970). The social responsibility of business is to increase its profits. The New York Times Magazine, September 13 pp.173-178. Retrieved July 20, 2015, fromhttp://www.colorado.edu/ studentgroups/ libertarians/issues/friedman-soc-resp-business.html

Hariharan, K., Williams, J., (2011). Greening the Business Curriculum through Collaborative Learning Spaces: Theoretical and Practical Perspectives, Malaysian Journal of Distance Education 13(1), pp. 35-45

Heidt, T., and Lamberton G., (2011) Sustainability in the undergraduate and postgraduate business curriculum of a regional university: A critical perspective, Journal of Management \& Organization, Volume 17, Issue 5, September, pp. 670-690. 
Higher Education Act, supplemented and amended, SG, issue 56 of 24 July 2015.

Husted, B. W., \& Allen, D. B. (2000). Is it ethical to use ethics as strategy? Journal of Business Ethics, 27(1-2), pp. 21-31.

Jacob Park, J., Sarkar, R., Bunch, R.,(2012). Sustainability and Management Education in China and India: Enabling a Global Green Economic Transition, 2012, Business Leadership Review IX, January, pp. 1 - 15.

Kolodinsky, R.W, Madden, T.M, Zisk, D.S \& Henkel, E.T (2010).Attitudes about Corporate Social Responsibility: Business Student Predictors, Journal of Business Ethics, Vol. 91, Iss. 2, pp. 167- 181.

Matten, D. \& Moon, J. (2004), Corporate social responsibility education in Europe. Journal of Business Ethics, 54, 323-337.

McWilliams, A., Siegel, D. S., \&Wright, P. M.. (2006). Corporate social responsibility: strategic implications. Journal of Management Studies, 43(1), pp.1-18.

Molteni, M. (2006) The social-competitive innovation pyramid. Corporate Governance, 6(4), pp. 516-526.

Munilla, L, Bleicken, L., \& Miles, M. (1998). Social responsibility and AACSB accreditation standards: How ISO 14000 can integrate environmental issues into the marketing curriculum. Marketing Education Review, 8(3), pp. 57-65.

Navarro, P., (2008). The MBA Core Curricula of Top-Ranked U.S. Business Schools: A Study in Failure? Academy of Management Learning \& Education, Vol. 7, No. 1, 108-123.

Nidumolu, R., Prahalad, C. K,.\& Rangaswami, M. R.. Why sustainability is now the key driver of innovation. Harvard Business Review, September, 57-64, 2009.

Okoye, A., (2009). Theorising Corporate Social Responsibility as an Essentially Contested Concept: Is a Definition Necessary? Journal of Business Ethics, November, Volume 89, Issue 4, pp. 613-627.

Overton, R., N., (2006). Teaching Ethics In The Financial Planning Curriculum: A Case Study, Journal of Business \& Economics Research,March Volume 4, Number 3, pp. 23- 28.

Porter M., Kramer, M. (2011). Creating Shared Value, Harvard Business Review, January-February, pp. 62-77.

Porter, M., Kramer, M., (2006). Strategy and society: the link between competitive advantage and corporate social responsibility, Harvard Business Review, December, pp. 76-92.

Rezaee, Z, Homayoun, S. (2014). Integrating Sustainability Education in to Business Curriculum:An Analysis of Existing Syllabi, Journal of Business and Economics October, Volume 5, No. 10, pp. 1877-1891.

Rundle-Thiele, S. R. \& Wymer, W.,(2010). Stand-alone ethics, social responsibility, and sustainability course requirements: A snapshot from Australia and New Zealand. Journal of Marketing Education, 32(5), 5-12.

Sanford, J., Motwani, J. (2013). Integrating Sustainability into a Business Course, R Revista Empresarial Inter Metro / Inter Metro Business Journal Fall 2013 / Vol. 9 No. 2 / p. 58-70.

Segon, M, and Booth, Ch. (2009). Business Ethics and CSR As Part Of MBA Curricula: An Analysis of Student Preference,International Review of Business Research Papers Vol. 5 No. 3. April, pp. 72-81.

Seto-Pamies, Domingo-Vernis and Rabassa-Figueras (2011). Corporate social responsibility in management education: Current status in Spanish universities, Journal of Management \&Organization,Valume 17, Issue 5, Septemeber, pp. 604-620.

Sharma, U, Stewart, B \& Kelly, M.,(2012). Education for Sustainability in the accounting curriculum at a New Zealand University, 2012 Retrieved from criticalperspectivesonaccounting.com/wp-content/.../ paper-cpa-013.doc, Accessed, 20 August 2015

Slavova, I., BankovaY. (2014). Corporate social responsibility in Bulgaria - part of European social practices", Publishing complex -University of National and World Economy, Sofia).

Smith, N. C. (2003). Corporate Social Responsibility: Whether or How? California Management Review, 45(4), pp. 52-76.

Strategy for Development of Higher Education in the Republic of Bulgaria for the 2014-2020 Period, Ministry of Education and www.journals.cz
Science, Bulgaria, Sofia, 2014 г. , p.9 , Retrieved October, 18, 2015 from http://www.mon.bg/?go=page \&pageld=74\&subpageld=143

Stubbs, W. and C. Cocklin (2008). Teaching sustainability to business students: Shifting mindsets. International Journal of Sustainability in Higher Education 9(3), pp. 206-221.

The UN Decade of Education for Sustainable Development (DESD 2005-2014); The First Two Years, 2007 UNESCO, Retrieved October, 17, 2015 from http://unesdoc.unesco.org/images/0015/ 001540/154093e.pdf

White, A., (2005). Fade, Integrate or Transform?The Future of CSR, Retrieved August,25, 2015, from www.jussemper.org/newsletters/ resources

Wilson, E \& von der Heidt, T. (2013). 'Business as usual? barriers to education for sustainability in the tourism curriculum', Journal of Teaching in Travel \& Tourism, vol. 13, no. 2, pp. 130-147.

Winter, J., Barton, G., Cotton, D. (2015).Learning development and education for sustainability: what are the links? Journal of Learning Development in Higher Education, Issue 8: March 5 pp. 2-22.

Wu, Y., Nuang, S., Kuo., Wu, W. (2010). Management Education for Sustainability: A web-based content analysis. Academy of Management Learning \& Education, 9(3), 520-531. 